\title{
THE HERMENEUTIC POWER OF CHARACTONYMS: A CASE STUDY
}

\author{
Yana MANOVA-GEORGIEVA, Elena ANDONOVA-KALAPSAZOVA \\ South-West University “Neofit Rilski”, Blagoevgrad, Bulgaria \\ E-mail: yana_georgieva@swu.bg; andonova.elena@swu.bg
}

\begin{abstract}
The aim of the article is to analyze the symbolic meaning of the name of Havelock Vetinari, one of the most recurrent literary characters in Terry Pratchett's Discworld series. The focus of the discussion are the literary and historical associations embedded in his name and his titles, which help the informed reader comprehend the complexity of the character's behavior in the narratives. The intertextual appropriations and echoes at the heart of the name derive from the author's multilayered encyclopedic knowledge that underlies the coining of the character's name. Havelock Vetinari is a noteworthy example of how the invented name of a literary character can become a powerful tool for meaning making in literature.

The study is carried out within the theoretical framework of the hermeneutic approach according to which a whole is understood as the synthesis of the numerous parts it consists of and the multifaceted interrelations among them. The analysis of Vetinari's name is thus conducted as a process of engaging in turn with the meaning of his given name, his family name as well as his official titles of address and nicknames, and looking into the linguistic, historical, and cultural associations they evoke which are correspondent to the nature of the literary character.
\end{abstract}

KEYWORDS: symbolic names, hermeneutics, hermeneutic circle, Discworld, Terry Pratchett, Havelock Vetinari, charactonyms

\section{Introduction}

Symbolic names in literature are often considered "meaningful", which, as Sims (2013, p. 153) puts it: "pull back the skin of your characters and can be analyzed quite like literature itself". Fowler further suggests that: " names in literature are not inherited like this: a fictional character's name must be found or invented- if, that is, the character is to be named at all" $(2012$, p.14). In fantasy literature in general and in the Discworld series, in particular, some of the main characters' names sound similar to the names of real historical figures to which slight alterations have been made. They vary from old names that are no longer in use to newly-invented names or name structures which allude to certain characteristics that a personage possesses. A method that has proved particularly productive in this respect is that of adapting the phonological sound or the spelling of a literary name to a foreign model so as to add an allusive meaning to it. This is what Vlahov and Florin consider a meaningful name, one that evokes allusion, possesses a suitable phonological pattern or resembles a real personage whose qualities can be attributed to a name bearer of interest. ${ }^{1}$

The importance of finding the right names for fictional characters has been equally assertively argued by authors and critics. Proper names are part of every natural language and thus they form an object of interest of micro linguistics, on the one hand, and of macro linguistics, on the other, as they reflect the society, history and culture of the language that has produced them. This is even truer when it comes to invented names holding a symbolic meaning in literature. In talks she has given on writing fiction, Joyce Carol Oates has spoken about "her deep feeling for her character and about her commitment to creating just the right name for every one." (Sims, 2013, p.151) Benedicta Windt's argument for the use of literary theory towards developing literary onomastics has drawn on Roland Barthes' theorizing on the significance of names in literature, in particular, the work of Marcel Proust. (Windt, 2006, p. 114). An essential aspect of the analysis of fictional characters' names is their consideration in relation to the plot and the character to whom they are given. Such relations are often ones of meaningful dialogue and so, the analysis will be looking at moments from different Discworld novels that reveal instances of such meaning-generating dialogicity.

The names, whose symbolic meanings that this article undertakes to analyse are those given to Havelock Vetinari, one of the most recurrent literary characters in Terry Pratchett's Discworld series. In the focus of the discussion are the literary and historical associations which have been embedded in his name (and titles) by means of the intertextual appropriation of characters and character traits found

\footnotetext{
${ }^{1}$ Vlahov and Florin (1990, p. )
} 
not only in the texts of fictional literature and of the historical record, but also in the larger 'textual fabric' of the collective cultural and historical memory ${ }^{2}$. The associations evoked often both support and ironically comment on the fictional character's nature as it is revealed in his thoughts and emotions, beliefs and behavior in the narrative and also enrich the informed reader's experience of the text.

The analysis is conducted in the framework of the so-called hermeneutic circle the basic idea of which is that one's understanding of a text as a whole is established by reference to the individual parts and the understanding of each individual part, respectively, is interpreted in turn by its references to the whole. What is understood as the text to read and interpret here is the name Lord Havelock Vetinari with its adjoining titles. The analysis involves two stages, namely, an analysis of the whole the character's name and titles as a whole - by dividing it into parts - name, surname and titles - and analyzing each of them separately, followed by a synthesis of the parts to return to the whole again with an enriched understanding of it. The hermeneutic approach allows the meaning of a symbolic name to be analyzed as it emerges in the dialogue between the culturally and historically informed horizon of reader's expectations and the fictional world and characters created by the author.

\section{Discussion}

The full designation of the character analysed in this article is either Lord Havelock Vetinarithe Patrician of Ankh Morpork or Lord Patrician of the city-state of Ankh-Morpork. In both versions it consists of a given name - Havelock, family name - Vetinari and two titles - Patrician and/or Lord. In addition, in several books of the Discworld, he is also referred to by the nickname the Tyrant [of AnkhMorpork].

\section{Havelock}

The given name of the Patrician is Havelock. It is of Old Norse origin meaning sea war, sea contest or sea sport. In present-day English, it mostly occurs as a surname with different spelling variations Aveloc, Haveloc, Haveloch or Havelocke.

There are several versions of the etymology of the surname. One version suggests that the name means "the son of Havlok", previously having been used as a personal name which inclines to being of Danish origin ${ }^{3}$. Another version suggests that the surname was first recorded in Medieval English where it was borrowed from Old Norse. In the language of origin, the name is a compound noun Hafleikr, which literally means "sea game" where haf means "sea, ocean" [Icel. Swed. haf: Dan. hav sea, ocean.] and leikr stands for "play" or "game".

Yet another version adopts the view that Havelock is etymologically related to an English general, the surname being recorded in $1857^{6}$.

What is important, though, is that despite the differences between the meanings ascribed to the name in the etymological interpretations, they focus on Havelok the Dane - a figure that has a prominent place in the medieval literary tradition. The intermingling of history and legend so characteristic of the latter has made it difficult to trace down the possible point of origin for this character in the real world. The romance is known to the present readership in two full metric versions, one of which is in Norman French and the other - in English, both dated to the Anglo-Norman period. Most scholars place the written versions at the end of the $13^{\text {th }}$ century although, quite expectedly, the legend itself in its oral form, is believed to belong to a much earlier period (Whistler, 2018, p.2-3).

The romance presents to the reader the story of the dispossessed Havelok, prince of Denmark, whose life is spared thanks to the miraculous signs of his divinely appointed royal status and who after

\footnotetext{
2 The ubiquity of intertextuality in Pratchett's oeuvre has been widely acknowledged and discussed. Among the more recent analyses of this aspect of the novels is in Aleksander Rzyman's The Intertextuality of Terry Pratchett's Discworld as a Major Challenge for the Translator (2017).

${ }^{3}$ Bardsley, Ch. (1896). A Dictionary of English and Welsh Surnames. Oxford University Press

${ }^{4}$ Bosworth, J. "heaf." In An Anglo-Saxon Dictionary Online, edited by Thomas Northcote Toller, Christ Sean, and Ondřej Tichy. Prague: Faculty of Arts, Charles University, 2014. https://bosworthtoller.com/18238. (last retrieved 2/12/2021)

${ }^{5} \mathrm{https}$ ://forebears.io/surnames/havelock\#meaning (last retrieved 18/06/2021)

6 https://nameberry.com/babyname/Havelock(last retrieved 18/06/2021)
} 
a series of hardships regains the throne of his kingdom. Central to the romance and also significant with regard to its protagonist's relation to Pratchett's character is the theme of the king's perfect sovereignty, including law and legal practices, based on his blameless behavior and self-evident wisdom. As stated in the Introduction to the romance in Four Romances of England: King Horn, Havelok the Dane, Bevis of Hampton, Athelston, "Havelok is a walking metaphor for kingship", his body representing "the political virtues of a potential king" (Drake, 1997).

As a ruler Terry Pratchett's Havelock shares many similarities with Havelok the Dane from the medieval romance. His actions are motivated by his ambition to keep Ankh-Morpork functioning smoothly and being prosperous. In Guards! Guards! the Patrician is described as working to make the city function and develop, not taking anything for himself, for personal gain?

In Snuff Vetinari defines his vision of morality, legal practice and social justice by pointing out the following ethical issue: "Indeed, if a poor man will spend a year in prison for stealing out of hunger, how high would the gallows need to be to hang a rich man who breaks the law out of greed?"8 (Snuff, 2019, p. 22)

Both Pratchett's Havelock and his medieval prototype are rulers who feel bound, by their royal status but also by their moral principles, to work for their country. They secure social justice by providing fair treatment to their subjects.

As will be further demonstrated in the coming sections, Pratchett's choice of a legendary king's name as the given name of his fictional ruler is unquestionably deliberate. On the one hand it evokes the more general principles underlying feudal monarchic rule: kings are sole rulers, they are not elected by their subjects but by God and cannot be replaced during their lifetime, they find the ultimate solutions when important state matters are concerned, their decisions are unquestioned and are always the best possible in a given situation. On the other hand, it implicitly ascribes the particular virtues associated with Havelok - justice, honesty, and nobility - to Pratchett's ruler of the fictitious city-state of AnkhMorpork.

The connection between the two names, however, is more complex and goes beyond the continuity suggested so far. The plot of Men at Arms, for example, renders the appropriation of Havelok's name ironic for, according to Edward d'Eath's hypothesis, Havelock Vetinari is actually a usurper of the throne of Ankh-Morpork, which is the exact opposite of what the medieval Havelok is a foundling of royal blood, raised by a poor man's family and later restored to his princely status. In the novel, the medieval Havelok's fate is, again based on d'Eath's investigation and conclusions, imparted to Corporal Carrot, a foundling adopted and raised by a dwarf couple whom d'Eath sets out to restore to kingship. This playful disruption of the association of continuity initially suggested by the near identity of the Havelok - Havelock names and the shared virtues, foregrounded by the novels, raises questions about the scope and the limits to the signifying power of proper names to which long-lasting associations have attached.

Complexity and contradictoriness are characteristic of the figure of the Ankh-Morpork ruler and they are also made manifest in the tension arising in Men at Arms between the associations evoked by his given name Havelock, and his family name, Vetinari.

\section{Vetinari}

Both the form and the meaning of the name suggest an Italian connection in Vetinari's pedigree. The allusion is strengthened by the mention that he was brought up by his closest relative, his aunt Lady Roberta Meserole -introduced in Night Watch as the woman from Genua, a fictional city whose name is identical to the Latin version of the name of Italian city of Genoa.

From a word-formation perspective the family name Vetinari is a clipping of the word veterinary, defined as "a medical person relating to the medical or surgical treatment of animals".

\footnotetext{
${ }^{7}$ Pratchett, T. (1990) Guards! Guards, Transworld Publishers Ltd, London

${ }^{8}$ Pratchett, T. (2019) Snuff, Knopf Doubleday Publishing Group

${ }^{9}$ https://www.merriam-webster.com/ (last retrieved 6/12/2021)
} 
To reinforce the Italian connection Terry Pratchett has preserved the Italian orthographic form of the name which is spelt with a final " $i$ ", and which is untypical for English, thus encouraging the English general readership to identify its Italian origin, or at least perceive it as foreign.

Gideon Habercorn has followed the possible suggestions of this choice of family name for the ruler of Ankh-Morpork and has pointed out the connection, based on semantic overlap, between the family name Vetinari and the name of the powerful aristocratic Medici family ruling Florence during the Renaissance (Habercorn, 2014, p.164).

The similarity is explained on the following grounds: first, both Vetinari and the Medici are the undisputed sole rulers in their city-states, and second, both the Vetinari and the Medici names denote medical doctors ${ }^{10}$. The name Medici itself is etymologically bound with the common words medicine and medication. Studies of the etymological origins of the word medicine have pointed out the connection, through the shared root - med, the first meaning of which is thought, but which also has the potential to denote schemes - with "the Medea of Greek tragedy, Medea the Sourceress, the Schemer, the Cunning" (Charen, 1951, p. 217). Medea, Jason's wife from the Argonauts cycle, who was a sorceress and priestess of the goddess Hecate and who, according to the legends committed several murders including the murder of her own children, was able to use herbs, potions and concoctions for the purposes of both healing and killing. As such she functions as a warning about the possible lifedestroying uses of the said curing substances and thus destabilises the association of the Vetinari and Medici names with healing only and makes them equivocal, pointing to the possibility of the abuse of medicinal knowledge too.

Both the Medici and the Borgia families became infamous for having used poison to get rid of their enemies. There are numerous records testifying to the use of the dark art of poisoning by members of both families. The Medici Granducal Archives - digitized and made accessible for study by scholars as part of the Medici Archive Project - abound in evidence of the various members of the Medici family having resorted to the arts of poisoning. This aspect of the Medici life has even suggested one possible interpretation of the images - five red balls and one blue on a gold shield - on the family coat of arms: "According to sixteenth-century genealogists the balls supposedly represent pills, because "Medici" is the plural of medico, "physician" in Italian." (De Roover, 1946, p.120). Even though, as De Roover noted, this theory has already been discredited, the association has retained a place in popular consciousness. With regard to the Borgias, the historical records are also rife with evidence of the ingenious ways in which members of this family used poison as a deadly weapon.

The allusions connecting Vetinari with both Italian Renaissance families are multifaceted and scattered in many places across the Discworld novels. The use of poison and poisoning as a practice employed in dealing with one's political adversaries feature in Vetinari's life and so confirm the suggestion, initially signaled by the name, of a link with both the Medici and, by proxy, the Borgias. However, a reading that goes beyond the name to engage with the character in light of the suggested connection to the Medici and the Borgias ultimately reveals the connection to be a complex one and Pratchett's ruler to be a parodically reversed version of his Italian prototypes.

The relation of Vetinari to the practices of both healing and poisoning is not a straightforward one. Rather than being the ruler capable of yielding these powers, Ankh-Morpork's monarch finds himself at the receiving end. Towards the end of Men at Arms, for example, he is actually shown ruminating the curing/killing effect of a drink, which has been administered to him by the Archchancellor. He is never said to have used poison to make sick or to kill anybody and as far as curing is concerned, he is implicitly denied that power, once attributed to monarchs too. This is done through Lord Rust's derisive words regarding monarchs' healing powers and Edward d'Eaths supposed belief in them: Young Edward thinks the touch of a king can cure scrofula, as if royalty was the equivalent of a sulphur ointment.

\section{Vetinari's Italian Connection}

Vetinari as an (ex-)Assassin

We learn from the Discworld novels quite a lot about Vetinari's youth. He is a descendant of a powerful family who has lost his parents early in his childhood and is brought up by his aunt. When he is young, on the advice of his aunt Masserole, he enrolls as a student at the Assassin's Guild, supposedly

\footnotetext{
${ }^{10}$ In Modern Italian the word medici is the plural form for doctors.
} 
in order to continue the family tradition. The Guild of Assassins is deliberately chosen because apart from preparing its students for the occupation of a paid murderer, it also offers its students prestigious academic education. Vetinari graduates from the Guild with outstanding marks and with several different qualifications, some of which are quite obviously ridden with internal contradictoriness: Doctor of Medicine \& Applied Pathology, Doctor of Music, Doctor of God Studies, Master Assassin, Master of Political Expediency, Master of Alchemical Science, Member of the Institute of Dance \& Deportment, Bachelor of the Science of Inhumation and a Diploma in Physical Education. He has also gone on to become the Guild's Provost as evidenced in the Discworld's Assassins' Guild Yearbook and Diary 2000.

One of the occasions on which Vetinari is called upon to employ the knowledge and skills he has mastered as a student of the Assassins Guild is the "Glorious 25th of May" revolution. The role assigned to him in this momentous event is the assassination of the Patrician of AnkhMorpork, Homicidal Lord Winder (Night Watch, 2003). Ironically enough, Vetinari brings about Winder's death by NON-ASSASSINATION as the latter dies at the mere sight of Vetinari who appears in front of him dressed up in the complete assassin outfit. The killing of a tyrant that Vetinari takes up as his responsibility is an early sign of his concern for the welfare of the people of Ankh-Morpork. His response to the question about his identity and his purpose in seeking out Lord Winder adds further substance to this understanding of the character. The words: 'I come from the city' are of key significance for, besides literally indicating the place from which Vetinari comes, they also carry the implied message of Vetinari's motive for getting rid of the Patrician - the word city here metonymically also denoting Ankh-Morpork's population on whose behalf and for whose welfare Vetinari acts.

His deeds as a ruler are reported in the novels as highly valued and much respected by the people of Ankh-Morpork. The high esteem in which Vetinari is held by his subjects is one more touch point with the historical prototype of Lorenzo di Medici after whose death it was recorded in the Decree of the Signoria and councils of Florence that:

He "neglect[ed] no opportunity of protecting, increasing, adorning and raising this city, but was always ready with counsel, authority and painstaking, in thought and deed; shrank from neither trouble nor danger for the good of the state and its freedom.” (Williamson, 1974, p. 268-269)

Like Lorenzo, Vetinari is presented as a ruler determined to take all possible, even the most extreme, measures to deter any attempt by anybody (or anything) to threaten the prosperity of the city. In the novels his assassin's nature and readiness to undertake the task of killing his enemies if it would contribute to the peace and prosperity of the city is rendered in jocular statements like: "The Patrician was not a man you shook a finger at unless you wanted to end up being able to count only to nine." (Guards! Guards!,1990, p. 56) or "If per capita was a problem, decapita could be arranged." (Reaper Man, 1991). However, Vetinari is very careful not to exercise his power as a sole ruler beyond sheer necessity. This aspect of his ruler policies Pratchett again renders in his characteristically humorous manner, this time pivoted on the homonymic reign-rain pun: "He didn't administer a reign of terror, just the occasional light shower." (Sourcery, 2012, p. 97).

\section{Vetinari's political philosophy}

The body of political principles that can be identified as supporting Lord Vetinari's rule in the Discworld is one of the areas in which the connection between his character and those of the two historically prominent figures in late $15^{\text {th }}$ century Italy - Lorenzo the Magnificent and Cesare Borgia has been made particularly prominent.

Vetinari's private life is a secret, little is known about his personal affections and aversions. His life story is veiled and what is known about him is based on rumours which have turned into legends, rather than on facts. Even his time in the Guild of Assassins is not supported by records, as all documents related to his studies there have mysteriously disappeared after his graduation. His only real life is the official one as the Patrician of the city. In Thud! his rule is described metaphorically as "a room full of tension, with people bickering and shouting at one another, and "in the middle of it all, one man, quietly doing his own thing". 
Lord Vetinari is reserved and reticent. He is skeptical, suspicious and cynical when it comes to making important decisions that will protect the city of Ankh-Morpork and guarantee its future development.

Most of these distinctive features of Vetinari's philosophy as a ruler suggest relatedness to the political principles elaborated in the work of Niccolo Machiavelli, who is known to have spent over a year at Borgia's court - one of a number of diplomatic missions on which he was sent between 1499 and 1512 (Viroli, M., 2005, xi). During this time, he followed Cesare Borgia in his conquest of new territories, took notes of his actions and regularly sent reports to his superiors in Florence. Most of these notes and reports were later included in Machiavelli's Collected Works and his seminal Il Principe (The Prince). The book published posthumously in 1532 is devoted to the Medici family but the main hero in it is Cesare Borgia.

It has been unanimously agreed on by scholars that it is the first tractate discussing matters of political philosophy based on the author's direct observations of the actions of Cesare Borgia as a ruler of Romagna in his attempt to establish a new principality. The central focus of Machiavelli's reflections in the book is Cesare's skill and the policies he employed in ruling Romagna.

Machiavelli reflects on the qualities that an ambitious ruler should possess and the methods he should adopt in order to come to power as well as the tools that he can then apply in order to stay in power and maintain stability. In discoursing on this he asserts, for example, that "every prince must desire to be considered merciful and not cruel" (Machiavelli, N. 2005, p. 57) only to then refer to Cesare Borgia pointing out that he:

was considered cruel; nonetheless, this cruelty of his brought order to the Romagna, ${ }^{*}$ united it, and restored it to peace and loyalty. If we examine this carefully, we shall see that he was more merciful than the Florentine people, who allowed the destruction of Pistoia in order to avoid being considered cruel. Therefore, a prince must not worry about the infamy of being considered cruel when it is a matter of keeping his subjects united and loyal. (2005,p. 57)

In The Prince he explains that people are by nature ungrateful, inconstant, hypocritical, cowardly and avaricious. When their services are not immediately needed, they claim they are faithful, they offer their blood, their property, their life and their children, but once they feel that demand of their services is imminent, they turn their backs straight away. The conclusion Machiavelli comes to is that a ruler who trusts such people's assurances and does nothing to secure himself, runs the risk of failure.

The same rather pragmatic and to a great extent cynical view about the essence of human nature is evident in the following Vetinari's statement: "I believe you find life such a problem because you think there are the good people and the bad people," said the man. "You're wrong, of course. There are, always and only, the bad people, but some of them are on opposite sides." (Guards, Guards!, 1990, p. 391)

One of Machiavelli's precepts as a political theorist was the necessity of employing violence on occasions when order and the peace were being threatened. Arguing his point he referred to Cesare Borgia and his reputation as a cruel ruler and went on to defend him as a man whose cruelty "brought order to Romagna, united it, and restored it to peace and loyalty" (The Prince, 2005, p. 57). A strong negative reaction to this view has marked the reception of The Prince almost from the very beginning. Machiavelli's opponents claimed that such a view advanced "evil recommendations to tyrants to help them maintain their power" (Giorgini, 2013, p. 625). In words, strongly reminiscent of Machiavelli's on the need to recognize "the quality of the times" (The Prince, 2005, p. 85) and whether they require or forbid the use of violence, Lord Vetinari states with a hint of black humour that: "The world is changing and it needs its shepherds and sometimes its butchers." (Raising Steam, 2019, p. 475).

The balance between the love of the subjects and their fear from the ruler is also one of the central topics in Machiavelli's The Prince. He comes to the conclusion that people are less hesitant when it comes to confronting a ruler they like, than confronting a ruler they fear, which implies that a tyrannical ruler is less threatened by riots and disturbances than a democratic one.

It is for a reason that Vetinari's most popular nickname is The Tyrant, fully corresponding to the designation of 'a tyrant' as an absolute ruler unrestrained by law or constitution ${ }^{11}$. In a hilarious

${ }^{11}$ https://www.merriam-webster.com/ (last retrieved 6/12/2021) 
perversion Pratchett explains that after Ankh-Morpork had experienced many forms of government, the city finally adopted a form of democracy based on the "One Man, One Vote" principle where: "The Patrician was the Man; he had the Vote" (Mort, 2012, p.184). Vetinari is fully satisfied with this state of affairs. He believes that society needs a tyrant because it subconsciously expects the tyrant to take care of the social stability and safety of the world around. Whimsically he explains: "One day it's the ringing of the bells and the casting down of the evil tyrant, and the next it's everyone sitting around complaining that ever since the tyrant was overthrown no one's been taking out the trash". He goes on explaining that: "Every evil tyrant has a plan to rule the world. The good people don't seem to have the knack." (Guards! Guards!, 1990, p. 300), which, according to him, justifies his right to be the tyrant of the city because of his extraordinary intellect.

\section{Vetinari - Innovations and the Arts}

Lord Vetinari is linked with both the Medici and the Borgia families along another line, namely his interest in modern technological inventions and the arts. Apart from becoming infamous for resorting to corruption practices and using violence and murder, as Renaissance rules, both the Borgias and the Medici were characterized by their affinity for and patronage of the Renaissance arts, sciences and humanist thought. Like them, Vetinari is a man with a keen interest in scientific discovery and innovation. Ironically undermining the inscription on his Coat of Arms - Si non confectus, non reficiat meaning "If it ain't broke, don't fix it", Vetinari, in fact, takes interest in all sorts of innovation that hold the promise of helping him retain his position as a ruler, on the one hand, and protect the city and help it prosper, on the other.

As ruler of the city, Vetinari introduces many new policies, some of which seem illogical or even contradictory. For example, he encourages the growth of the public services by legalising the Thieves' and the Assassins' Guilds, which at a first glance is paradoxical. The Thieves' Guild is authorized with the punishment of unlicensed stealing, while the Assassins' Guild is assigned the task of punishing uncontracted killing. In this way the two Guilds are made part of the public services which bring about the decline of the criminal rate in the city. Vetinari also establishes the institution of The City Guards under the commandment of Captain Vimes to protect the citizens and fight crime (Feet of Clay 1997). Under the Patrician's careful guidance, the three institutions develop into a hefty, resourceful, efficient machine that enables the city's smooth operation.

Vetinari encourages and supports many new initiatives in the spheres of information and communication such as the founding of the first local newspaper Ankh-Morpork Times (The Truth, 2013), the AM-based Grand Trunk Clacks Company, by means of which the first efficient international communication service is established (The Fifth Elephant 2013), the first post office (Going Postal, 2014), and introduces the first banknotes, by implementing postal stamps as means of monetary exchange (Making Money, 2014).

His strategy to take Ankh-Morpork into the future is embodied in his ambitious plan to build an underground, a project he titles 'The Undertaking', which appears somewhere between Thud! and Making Money, and which is inspired by the discovery of a perpetual mobile machine. The project includes the construction of underground streets, waterproof tunnels and 'new docks' using the already implemented new sewerage system.

Vetinari's relation to innovations and the arts is further consolidated by the presence in the Discworld novels of another character - Leonard of Quirm, whose prototype is the Renaissance genius Leonardo da Vinci. Leonard is the Discworld series' parodic counterpart of Leonardo and he appears mainly in five of the Discworld novels: Wyrd Sisters, Men at Arms, Jingo, The Fifth Elephant and The Last Hero. The name of this character Pratchett modelled on the original Italian name structure, inviting in this way not only the association of Leonard of Quirm with da Vinci but also the perception of the relation between Vetinary and Leonard of Quirm in terms of the patronage that defined the relations between the Medici and the Borgia families as well as the outstanding Italian Renaissance artists among whom Leonardo da Vinci was an outstanding figure.

Leonardo was introduced to the Medici family through his work for Verrocchio, the Florentine artists who is known to have worked on a range of commissions from Lorenzo de Medici. Leonardo was apprenticed to Verrocchio at an early age and was part of his workshop for several years during which he studied the arts of painting and sculpture and also acquired skills demanded for what Clark 
and Kemp define as that other "most vitally important of all the arts" during the Renaissance - war, evidence of which is found in Leonardo's drawings of military devices from this period (Clark, K. and Kemp, M., 1993, p. 84). Both the Medici and the Borgia families depended on these war-related skills of the Renaissance artists and in the case of Leonardo this is perhaps nowhere more visible than in the work he performed for Cesare Borgia as military engineer and architect (Sabatini, 2011, p. 257).

Like Cesare Borgia who hired Leonardo, Vetinari hires Leonard of Quirm, who shares his prototype's fame as a genius painter, engineer and scientist. While the Discworld novels give credit to Leonard's painterly talents as evidenced by his "'Woman Holding Ferret" and "Mona Ogg", they also dwell extensively on his genius for invention and engineering. His designs and devices range from the labour-saving ones, such as "The Very-Fast-Coffee Machine" for making espresso (The Fifth Elephant), through the entertaining "Make Words With Letters That Have All Been Mixed Up Game" (Jingo), to the radically progressive ones like the submarine (the Going-Under-The-Water-Safely-Device in Jingo) and the airplane ( "flying device" in The Last Hero) to the downright dangerous "infernal combustion engine" (Jingo) and the design for a "throwing arm for the balls of molten fire" (Jingo). Leonard's eversearching mind and thirst for knowledge lead him to invent powerful machines some of which, having the potential to bring about destruction on a massive scale, could be put to military uses. That Vetinari is fully aware of this as well as of the artist's naïveté which prevents him from fully comprehending the implications of his inventions, is evident from the Patrician's thoughts about him, both in Jingo and in The Fifth Elephant:

The worried man in front of him, who was so considerate of life that he carefully dusted around spiders, had once invented a device that fired lead pellets with tremendous speed and force. He thought it would be useful against dangerous animals. He'd designed a thing that could destroy whole mountains. He thought it would be useful in the mining industries. Here was a man who, in his tea break, would doodle an instrument for unthinkable mass destruction in the blank spaces around an exquisite drawing of the fragile beauty of the human smile. With a list of numbered parts. And if you taxed him with it he'd say: ah, but such a thing would make war completely impossible, you see? Because no one would dare use $\mathrm{it}^{12}$.

What for Leonard is simply a "throwing arm for the balls of molten sulphur", for Vetinari is a "war machine" (Jingo, 2014). It is this naïveté of Leonard's that makes the Patrician keep him locked up in his room - a "permanent guest" in the Patrician's Palace, a euphemism for 'prisoner'. The ambiguity at the heart of this phrase hints at the complexity of the relationship of patronage between Vetinari and Leonard, and more generally, between monarch-patrons and artists, which did not only rest on the benevolent attitude of the patron but could also accommodate the latter's rigorous disciplining practices. Even though Leonard's confinement to the privacy of his own room is represented as his own choice there is also the suggestion that it is a lucky coincidence with the Patrician's preferences which, if lacking, Vetinari could nevertheless enforce submission on the authority of his rulership. The relationship between Vetinari and Leonard reveals the Patrician as an ironically constructed version of the Renaissance monarch and patron of the arts - a man appreciative of artistic and scientific talent and work, but also calculating with regard to strategic, political and other benefits that could be drawn from them. The narratives of Jingo and The Fifth Elephant contain a number of hints to the latent possibility of Vetinari making use of the warfare machinery which Leonard has designed merely as "an intellectual exercise" (Jingo, 2014, p.97).

\section{Vetinari's Titles}

The full designation of Vetinari contains two titles, namely Lord and Patrician. He is referred to either as Lord Havelock Vetinari - the Patrician of Ankh Morpork or Lord Patrician of the city-state of Ankh-Morpork, as previously mentioned.

The title Patrician goes along the Italian strain, while Lord, along the Germanic one, respectively. What lies in the Italian strain is the tendency of aristocratic families of Ancient Rome to be called patricians. The title later became a vague term used for aristocrats and the higher bourgeoisie in many European languages. In modern English usage patrician is a synonym of "aristocratic".

${ }^{12}$ (The Fifth Elephant, 2013, p.83) 
As far as the title lord is concerned, it is of Anglo-Saxon origin and is used as an appellation for a person or deity, usually capitalized, who possesses authority, control, or power over others. The title lord later started being used as a generic term to denote members of the peerage and as an indication for their aristocratic background.

Both titles presuppose Vetinari's aristocratic bloodline and their use together is to some extent a tautology, deliberately sought by Pratchett to reinforce the intended meaning behind the name and aiming at the amalgamation of two major European cultural traditions.

One typical feature of the British aristocracy is said to be their ability to keep a stiff upper lip. The phrase traditionally describes a behavioural strategy of British people and especially the British aristocracy, to remain resolute and unemotional when faced with adversity, to show "a quality of uncomplaining stoicism" ${ }^{\prime 3}$.

Lord Vetinari displays this type of typical Anglo-Saxon aristocratic behaviour in two ways: first, he can listen very carefully without interrupting his interlocutor being able to remain silent for an unusually long time during a conversation, and, second, to achieve his goals and persuade his opponents he often uses irony which has the force of a verbal deadly shot.

Listening by remaining silent is one of his most efficient weapons. Pratchett describes him in the following manner: "He was extremely good at listening. He created a kind of mental suction. People told him things just to avoid the silence". (Soul Music 2013:182) and also: "[...] he listened with great care because what people said was what they wanted him to hear. He paid a lot of attention to the spaces outside the words, though. That's where the things were that they hoped he didn't know and didn't want him to find out". (Jingo, 2014, p.15)

One of the best descriptions of this ability of his is found in Raising Steam where Pratchett says: Lord Vetinari could outstare a statue and make even a statue start to feel nervous and confess. (Raising Steam, 2019, p. 117)

Several of Vetinari's abilities such as his absolutely photographic memory, the ability to solve puzzles almost instantly and the apparent inability to get drunk, suggest he may not be entirely human and moves him closer to a kind of deity, which is, as mentioned above, the second meaning of the word Lord.

\section{Conclusion}

The figure of Havelock Vetinari which emerges from the dialogic interplay among references to several historical figures - Havelok the Dane, Lorenzo di Medici, Cesare Borgia, Pope Alexander VI, Machiavelli, their lives and, in the case of Machiavelli, texts authored by them - is a parodically reconstructed version of the dictator. The subtle and multifaceted network of associations has been activated through a number of ways of which the name of the ruler, together with his titles and nicknames is the one immediately noticeable to the critical reader. The character's name has combined two major cultural traditions from the political practices of Europe, his full designation suggesting both Italian and Germanic connections.

The associative links suggested by the character's name and titles open several interpretative perspectives on his behavior - verbal and physical, and on his emotional and mental experiences throughout the Discworld series. These perspectives the analysis has taken up by first looking into each of the names and titles evoked by Pratchett's character's name, their historical referents and significance and then by tracing which of their prominent character traits have been integrated into that of Pratchett's fictional character. The latter has been done by discussing the manifestations of Havelock Vetinari's character at various places in the novels. It is our belief that the adoption of this hermeneutic procedure which reaches beyond the confines of the novels' texts to consider the implications of historical and cultural references allows that the character's richly suggestive figure is comprehensively experienced. This approach allows the reader to broaden their individual horizon of literary competence and gain a better understanding of the character and his place in Terry Pratchett's Discworld series which, as a whole, can be viewed as a literary hypertext transforming the historical and cultural hypotexts. It involves the reader in a multilayered dialogue with the texts of the novels in which Vetinari features as a central character and, as a consequence of the many questions raised in the process, encourages the development of a critical attitude that looks beyond the world of literature to interrogate our ways of thinking as human beings, and enhance the possibilities of gaining a more profound understanding of our own world.

\section{REFERENCES:}

\footnotetext{
${ }^{13}$ New Oxford American Dictionary (2010). Oxford University Press
} 
Alton, A.H. and Discworld and the Disciplines: Critical Approaches to the Terry Pratchett

Spruiell, W.C. Works. New Carolina: McFarland \& Company. Inc. Publishers.

(2014)

Bardsley, Ch. (1896) A Dictionary of English and Welsh Surnames: Oxford University Press

Bosworth, Joseph

In: An Anglo-Saxon Dictionary Online, edited by Thomas Northcote Toller, Christ Sean, and Ondřej Tichy. Prague: Faculty of Arts, Charles University, 2014. <https://bosworthtoller.com/18238> (last retrieved 2/12/2021)

Charen, T. (1951) The etymology of medicine - In: Bulletin of the Medical Library Association, 39(3), p 216-221

Clark, K. \& Kemp, Leonardo da Vinci (Revised edition): Penguin Classics

M. (1993)

De Roover, R. (1946) The Three Golden Balls of the Pawnbrokers - In: Bulletin of the Business Historical Society, 20(4), doi:10.2307/3110507, p 117-124

Drake, G., Four Romances of England: King Horn, Havelok the Dane, Bevis of Salisbury. E and Hampton, Athelston

Herzman, R.B.

(1997)

Forebears.io

$<$ https://forebears.io/surnames/havelock\#meaning $>\quad$ (last retrieved

Fowler, Al. (2012) 18/06/2021) Literary Names: Personal Names in English Literature, Oxford University Press, $\quad<$ http://ebookcentral.proquest.com/lib/aubgebooks/detail.action?docID=1079716>, ProQuest Ebook Central

Giorgini G. (2013) Five Hundred Years of Italian Scholarship on Machiavelli's Prince. The Review of Politics, 75(4), doi:10.1017/S0034670513000624, p 625-640

Habercorn,

G. Debugging the Mind: The Rhetoric of Humor and the Poetics of Fantasy (2014) In: Alton A.H. and W.C. Spruiell (eds) Discworld and the Disciplines: Critical Approaches to the Terry Pratchett Works, New Carolina: McFarland \& Company. Inc. Publishers.
Machiavelli N. A Description of the Method Used by Duke Valentino in Killing Vitellozzo (1989) Vitelli, Oliverotto da Fermo, and Others, The Chief Works and Others, trans. Allan Gilbert. Durham and London: Duke University Press, p 163-169
N. The Prince. Oxford: Oxford University Press

Machiavelli

(2005)

Merriam Webster <https://www.merriam-webster.com/>(last retrieved 6/12/2021)

Dictionary

Nameberry.com

$<$ https://nameberry.com/babyname/Havelock>(last retrieved 18/06/2021)

New

Oxford

American

$<$ https://www.oxfordreference.com/view/10.1093/acref/9780195392883.00

Dictionary (2010)

Pratchett, T. (1990)

Pratchett, T. (1997) 1.0001/acref-9780195392883>

Pratchett, T. (2002)

Pratchett, T. (2003)

Pratchett, T. (2005)

Pratchett, T. (2012a)

Pratchett, $T$.

(2012b)

Pratchett, T. (2013a) The Fifth Elephant. Corgi Books. London: Transworld Publishers Ltd

Pratchett, $T$.

(2013b)

Pratchett, T. (2013c) The Truth. Corgi Books. London: Transworld Publishers Ltd

Pratchett, T. (2014a) Going Postal. Corgi Books. London: Transworld Publishers Ltd

Pratchett, $T$.

(2014b)

Guards! Guards, Corgi Books.London: Transworld Publishers Ltd,

Feet of Clay, Corgi Books. London: Transworld Publishers Ltd

The Last Hero. London: HarperCollins Publisher

Night Watch, Corgi Books. London: Transworld Publishers Ltd

Thud. London: HarperCollins Publisher

Mort. Corgi Books. London: Transworld Publishers Ltd

Sourcery. Corgi Books. London: Transworld Publishers Ltd

Pratchett, T. (2014c) Making Money. Corgi Books. London: Transworld Publishers Ltd

Pratchett, T. (2019a) Raising Steam: Knopf Doubleday Publishing Group

Pratchett, Terry

(2019b)

Snuff: Knopf Doubleday Publishing Group

Rzyman A. (2017)

The Intertextuality of Terry Pratchett's Discworld as a Major Challenge for the Translator. Cambridge: Cambridge Scholars Publishing. 
„ORBIS LINGUARUM “, VOLUME 20 , ISS UE 1

DOI: https://doi.org/10.37708/ezs.swu.bg.v20i1.20

Sabatini R. (2011 The Life of Cesare Borgia, The Floating Press

(1912)

Sims E. (2013) You've Got a Book in You, A Stress-Free Guide to Writing the Book of Your Dreams. USA: Writer's Digest Books

Vlahov, S. and Непреводимото в превода, [Neprevodimoto v prevoda], Sofia: Nauka i Florin, S. (1990) Izkustvo

Viroli, M. (2005) Introduction to Machiavelli, N. The Prince. Oxford: Oxford University press

Whistler, C. (2018) Havelok the Dane A legend of Old Grimsby and Lincoln. Frankfurt am Main:

Outlook Verlag. London: Thomas Nelson and Sons

Williamson H.R. Lorenzo the Magnificent. London: Michael Joseph Ltd

(1974)

Windt, B. (2006) Literary theory - an essential tool in the development of literary onomastics? $<$ https://www.semanticscholar.org/paper/Literary-theory-\%E2\%80\%93-anessential-tool-in-the-of-

Windt/fbbba2752f0a7bad65311162f1847623b408be00> 